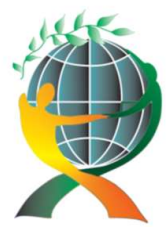

\author{
(online) $=$ ISSN $2285-3642$ \\ ISSN-L = $2285-3642$ \\ Journal of Economic Development, Environment and People \\ Volume 8, Issue 2, 2019
}

URL: http://jedep.spiruharet.ro

e-mail: office jedep@spiruharet.ro

\title{
The Hideouts of the Vaccination Process
}

\author{
Alexandru Mihai Stefanescu ${ }^{1}$ and Alexandra Rodica Stefanescu2 \\ ${ }^{1}$ The Bucharest University of Economic Studies, dr.alexstefanescu@gmail.com \\ ${ }^{2}$ ANIMA Clinic Bucharest, astefanescu35@yahoo.com,
}

\begin{abstract}
Vaccines are biological products prepared according to specific techniques meant to improve the body's immunity against particular, given conditions. According to World Health Organization (2017), along the time millions of children from 188 countries, immunized by different vaccines (diftero-tetano-pertussis acelular - DtaP, measles and polio) got their lives back.

In Romania, the anti-diphtheria vaccine introduced in 1960 allowed people's immunization and made the disease completely disappear in 1990. No case of diphtheria has been confirmed anymore so far. Since 2016, the immunization percentage has unfortunately, fallen below 90\% (CNSCBT, 2017) because of parents' refusal to administrate vaccines to their children and the failure in choosing and subscribing on a general practitioner's list. Nevertheless, today's society faces a dramatic situation caused by: a) lack and erroneous information of parents expressing their opposition to vaccination and b) particular manipulation of organizations against vaccines. The results of a field research are presented below together with socioeconomic consequences.

The purpose of this study is to quantify the people's knowledge about the immunization mechanism and their opinion linked to the advantages and the disadvantages of accepting vaccination. The paper outlines the low interest of the general population in vaccination given the fake news circulating through social media and the lack of updated information about the immunization actions' benefit.
\end{abstract}

Keywords: society, vaccination, general practitioner, public health programs

JEL: I10, I 11, I18

How to cite: STEFANESCU, A., \& STEFANESCU, A. (2019). The Hideouts of the Vaccination Process. Journal of Economic Development, Environment and People, 8(2), 14-23. doi:http://dx.doi.org/10.26458/jedep.v8i2.620

\section{Vaccination: Mechanism of Action}

The beneficial effect that vaccination has on the quality of life, population longevity and public savings has always been proven by specific statistics (Brugha \& Zwi, 1998). Vaccines keep within bounds the diseases' severity, reduce complications and decrease contagiousness.

The immunization programs (Abbas et al., 1994) rely on well-defined strategies aimed to monitor, assess, eliminate and eradicate certain diseases. The monitoring of a disease spread manages the limitation of that disease state until it is no longer a problem for the population. The elimination of any dangers phase is a greater challenge than to control them; it presumes the reduction to zero of cases of disease in a 


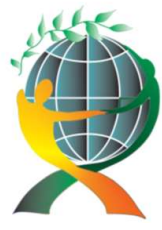

\author{
(online) $=$ ISSN $2285-3642$ \\ ISSN-L = $2285-3642$ \\ Journal of Economic Development, Environment and People \\ Volume 8, Issue 2, 2019 \\ URL: http://jedep.spiruharet.ro \\ e-mail: office jedep@spiruharet.ro
}

geographical area, although the pathogen still exists among the human or animal populations. The eradication of a disease is achieved when the pathogens disappear following vaccination; the only eradicated disease at this time is the smallpox.

Vaccines differ in composition, mechanism of action, infectious agents from which they are derived and the way they are administered. Thus, the viral vaccines are of three types: live attenuated virus vaccines (consisting of weakened strains of the infectious agent and lacking aggressiveness), inactivated virus vaccines (containing virions which after treatment with the inactivating chemical cannot multiply) and subunit vaccines (containing viral proteins extracted from the infectious agent). Vaccines are designed to protect against the unintended consequences of infectious disease with adverse or even life-threatening implications (Parker et al., 2006; Pearce, 2005). This is achievable by vaccinating the population with live attenuated or inactivated forms of pathogens that cause the growth of antibodies, B and T lymphocytes that will protect the individual against dangerous diseases. Then we can say that immunization is achieved.

The last week of April (WHO, 2017) marks and honors the immunization process through a week celebration. This is a great opportunity to perceive, understand, explain better and disseminate correct information about vaccines and immunization, from a holistic perspective (WHO, 2019).

According to the World Health Organization immunization represents the process by which any individual can gain access to resistance to an infectious disease by administering a specific drug that enables the body to fortify the immune system (Perelson, 1989) and creating a natural shield against infections or various communicable diseases (McMichael \& Beaglehole, (2009).

Immunization is a proven tool for controlling and eliminating life-threatening infectious diseases, favoring the illness and even the death of people.

Immunization is one of the most profitable public investments in health framed in different strategic programs by mechanisms recognized as international successful and useful practices, socially and economically profitable and accessible to all categories of people. As a process of health protection (Angheluta et al., 2016), the immunization mechanism is based on well-defined target groups open to communication through complex information channels and that do not require major changes in lifestyle.

Vaccination materializes both the right of any human being to keeping the body in proper health and individuals' obligation to consolidate the knowledge about preventative education (Petrakova \& Sadana, 2007) and gather to overcome fears and unknown and preserve the good status of health in good condition as one of the most important and strategic resource of the nation.

\title{
2. Benefits and Side Effects
}

Vaccines are the foremost tools used to support the public and individuals' health. To get the best results, immunization policy needs open communication and adequate publicity (Andre, 2005). Vaccines are valuable for their ability to control and hold disease by processes of elimination and then eradication. However, this does not remove the danger of the disease being reintroduced into an area where it has been eliminated, such as in: a) Botswana - the successful polio removal of 1991 was endangered in 2004 by an import of Type 1 polio virus from Nigeria (WHO, 2004), b) USA/Indiana - a Romanian tourist reintroduced measles in 2005 (Parker et al, 2006). 


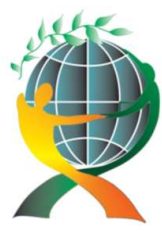

\author{
(online) $=$ ISSN $2285-3642$ \\ ISSN-L = 2285 - 3642 \\ Journal of Economic Development, Environment and People \\ Volume 8, Issue 2, 2019 \\ URL: http://jedep.spiruharet.ro \\ e-mail: office jedep@spiruharet.ro
}

Immunization brings benefits to the society as a whole too. Ehreth's predictions show that vaccines prevent every year over 6 million deaths worldwide (Ehreth, 2003). Nowadays, the USA registers significant decreases in number of death for those diseases for which vaccines have been recommended. Statistics show also an important decline in mortality and sequelae percentages. Complications that appear may have a more pronounced long-term effect than the disease itself. Over $40 \%$ of children surviving Haemophilus influenzae ( $\mathrm{Hi})$ meningitis may have permanent neurological defects (WHO, 2006).

Effective vaccines do not only protect vaccinated people; they also reduce illness among nonimmunized individuals. A vaccination percentage of less than $70 \%$ against Hib (Haemophilus influenzae type B) in Gambia was enough to eliminate the disease (Adegbola, 2005). Also, rubella, which is not dangerous for children, may present a real risk for pregnant women who have not become immune to rubella before pregnancy (WHO, 2017). In this sense, the concept of flock hymns involves vaccination of children as an aid to protect the pregnant woman from getting infected during the first trimester of pregnancy, which would increase the risk of fetal development abnormalities (congenital rubella).

Vaccines are important weapons to fight against cancer knowing that infection agents cause certain types of cancer (Brawley et al., 2011). Chronic hepatitis B infection leads to liver cancer while human papilloma virus (HPV) infection precipitates the cervical cancer. Vaccination against these pathogens should prevent associated cancers, as already noticed in hepatocellular cancer in Taiwan and China (Chang, 2003). In the near future, a decrease of the incidence of cervical cancer it is expected when using the vaccine against HPV An important asset for society and public budget is related to money saving. In 2003 Ehreth estimated that vaccination engendered a direct saving of billions of US dollars worldwide. The gain is increased with the number of antigens combined in the same vaccine.

Combined vaccines bring even more benefits: increased compliance, coverage, and injection safety.

Immunization programs are a better and more efficient investment than other public trenches such as wearing a seatbelt, chlorinating drinking water, or smoking cessation advice (Chabot, 2004). By reducing the need for antibiotics, vaccines appear to play an important role in preventing (Mihoreanu, 2016) the development of antibiotic resistance. Vaccines of the type of influenza and anti-hepatitis $A$ are also a real support for those who travel a lot.

Vaccines contribute to increase the life expectancy, women's empowerment, economic growth, or protection against bioterrorism (Braveman et al., 2001). Robust immunization programs act as a cornerstone for public health by reducing inequality, eliminating illness and suffering and increasing the national capital (Benisheva-Dimitrova et al., 2008).

Like any other medicine, the vaccines may also have certain risks and side effects: local, systemic, allergic.

The most common side effects that occur within hours of injection are usually local, slightly severe and self-limiting - edema, pain and redness at the site of the injection. In rare cases, local reactions can be very serious or severe. Systemic side effects are more extensive events including fever, malaise, myalgia (muscle pain), headache, lack of appetite, and more. The third type of adverse reaction to the vaccine is severe (anaphylactic) allergic reaction, even caused by a component or vaccine antigen. However, the incidence of this event is less than 1 in a million vaccinated people. Such events are treated as medical emergencies. Over time, vaccines have been accused of increasing the risk of or even causing multiple serious illnesses such as autism, multiple sclerosis, type 1 diabetes, Guillain-Barré syndrome, or autoimmune diseases 


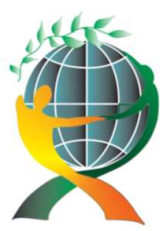

\author{
(online) $=$ ISSN $2285-3642$ \\ ISSN-L = $2285-3642$ \\ Journal of Economic Development, Environment and People \\ Volume 8, Issue 2, 2019 \\ URL: $\underline{\text { http://jedep.spiruharet.ro }}$ \\ e-mail: office jedep@spiruharet.ro
}

(Santamaria, 2010). These myths were, in turn, dismantled, through specialized studies showing that there is, in fact, no real statistical association between these pathologies and vaccination. In conclusion, we can say that the benefits of vaccination far outweigh the adverse reactions that some individuals may face.

\title{
3. About Vaccination in Romania
}

In Romania there is a planning of vaccination developed based on national schemes approved by central health authorities, according to the age of the child and established by legal norms, as follows: Hepatitis B vaccine - in the first 24 hours, Calmette Guerrin Vaccine (BCG) - for the first 2-7 days, Atherosclerotic polymorphitis-Haemophilus B-hepatitis B diphtheria-pertussis pertussis vaccine - 2 months, 4 months, 11 months, Conjugated pneumococcal vaccine - 2 months, 4 months, 6 months, MeaslesRubella-Mumps Vaccine - at 12 months, 5-7 years old, Atherosclerotic diphtheria-tetanus-pertussispoliomyelitis vaccine - at 6 years, Polio vaccine - 8 years old, Diftero-tetanic vaccine for adults / DTaP vaccine - 14 years of age (Lancaster and Stanhope, 2011).

To assess the population's awareness of vaccination and its role in disease prevention (CDCP, 2017), we used the data recorded in GPs medical offices and processed them under the rigor of a scientific survey to identify and assess the population's attitudes about vaccination and the reasons why some parents refuse it for their children (Swartz, 2004). The study, descriptive and transversal, was conducted by us, during the 15th of October 2015 until the 25th of March 2016. We applied a questionnaire to a group of 139 subjects ( 80 female and 59 male), aged between 21 and 63, through voluntary participation. The application of the questionnaire aimed at a relatively diverse population from the point of view of the background environment, the level of training, income, age and number of children.

The survey built on a set of 21 questions: some with preformed answers and others with open answers to be given in less than 5 minutes. The question sheet was handed to the respondent. The survey used variables of the quantitative (age) and qualitative type (environment of origin, gender, social status, level of training). Only adults have been considered and included in the study. We also considered the not returned questionnaires.

Data was collected by auto completion, keeping the respondent's anonymity and confidentiality. Data was collected after completing the questionnaire, then centralized and analyzed with Microsoft Office Excel, and then processed with Microsoft Office Word. We used graphical representations of the results obtained (Tarlov et al., 1989), radial structure diagrams, column diagrams, bar graphs and figures.

The Results of the Study

Summarizing the survey's figures, the majority of respondents belongs to the first groups of age: 29/139 are aged between 25-29 year old and 28 people belong to 30-34 years old group. The group of 6065 years is the lowest represented with only 2 respondents. Statistics show that people aged between $25-$ 34 years are more interested in a family status (marriage and children), and this is directly linked to their interest and knowledge about vaccination.

The respondents coming from urban areas $(71.28 \%)$ show also a higher interest in vaccination topics.

Most of the participants proved a high level of education: 46.04\% - (academic degree), 34.53\% secondary school), $14.38 \%$ - (professional studies); only $5.05 \%$ graduated only primary school. That outlines 


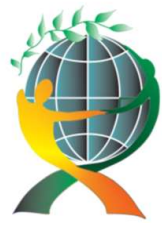

\author{
(online) $=$ ISSN $2285-3642$ \\ ISSN-L = $2285-3642$ \\ Journal of Economic Development, Environment and People \\ Volume 8, Issue 2, 2019 \\ URL: http://jedep.spiruharet.ro \\ e-mail: office jedep@spiruharet.ro
}

the idea that the interest in health prevention and immunization come along with a higher interest in education. Of a total of 95 subjects with children, 94 of them already vaccinated their children and only one respondent did not. This seems to be a good and encouraging situation as most parents have understood the importance of vaccination and chose this path of health prevention.

39 out of the 44 respondents without children state that they would accept to vaccinate their children, while 5 declared their disagreement with this method of health prevention. It has been noted the high number of people without children who refused the idea of vaccination.

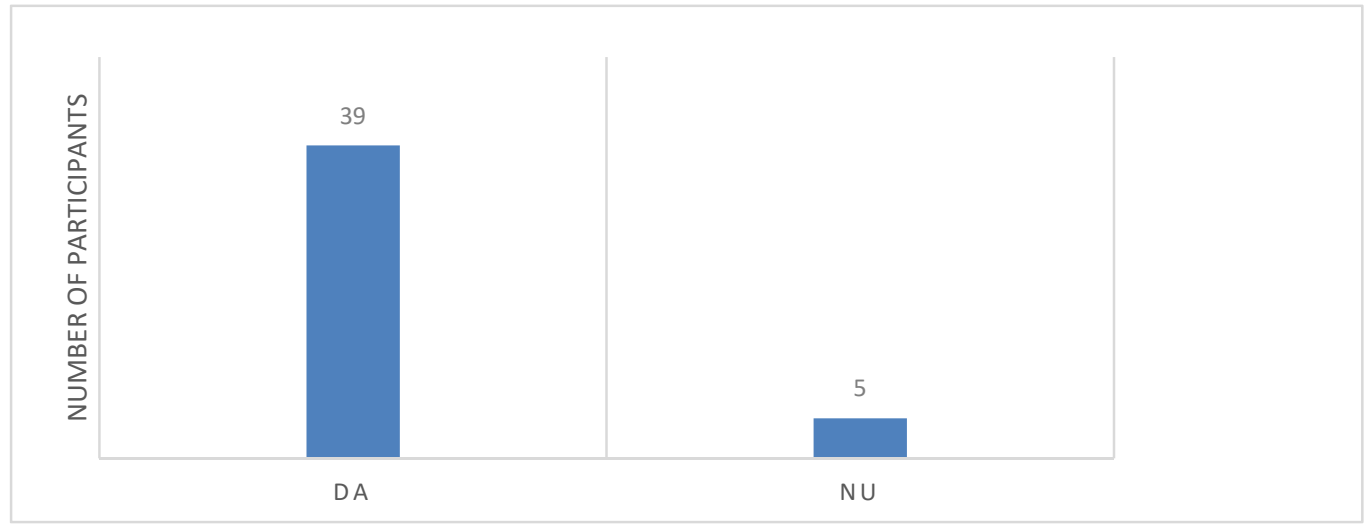

Fig. 1: The attitude of people without children in relation to vaccination

99 of all individuals surveyed knew that all vaccines on the list are mandatory in Romania. The vaccine against tuberculosis (BCG) was the second most important response chosen by 34 people, the reason being probably determined by the increased incidence and coverage of this disease. The least of the respondents knew that the hepatitis B vaccine is part of the mandatory vaccines in our country, probably because it was last entered into the free immunization list, only in 1995. However, there are no significant statistic differences between respondents with higher education than respondents without higher education ( $p>$ 0.05).

The answers name the family doctor (general practitioner) as the most frequent source of information $51.80 \%$. The literature occupies the second position followed by the social sources -Internet, television, friends and newsletters. The Figure 2 shows a good situation of the level of information among the interviewed population; over $80 \%$ of respondents use correct and updated sources of information.

After analyzing the participants' responses to the existence of legal sanctions for parents who refuse to vaccinate their children, it is noticed that $61.15 \%$ think that there should be no sanctions or constraints and the rest $38.85 \%$ think that such penalties should be expressed by the laws. Of the 54 respondents who believe that there should be sanctions, most (18 people) believe that a feasible constraint is to exclude children from communities by refusing authorities to enroll in educational institutions. A percentage of $11.51 \%$ of all respondents appreciate that there should be legal constraints, but without exemplifying methods of coercion. Of those who consider that there should be sanctions, $7.19 \%$ believe that there should be higher healthcare contributions. Some mentioned few ideas of punishment/constraints: fines, 


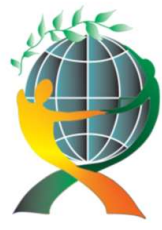

\author{
(online) $=$ ISSN $2285-3642$ \\ ISSN-L = $2285-3642$ \\ Journal of Economic Development, Environment and People \\ Volume 8, Issue 2, 2019
}

URL: http://jedep.spiruharet.ro

e-mail: office jedep@spiruharet.ro

insurances not to cover preventive diseases by vaccinating, health monitoring cancelation. 89 of the respondents declared that vaccination is better if applied clinics of proximity, by the general practitioner. 39 of those questioned did not have any opinion about the doctor who should vaccinate children-family doctor or school doctor. Without giving farther explanation, 14 of those interviewed relate the fact that the family doctor should not be responsible for vaccination.

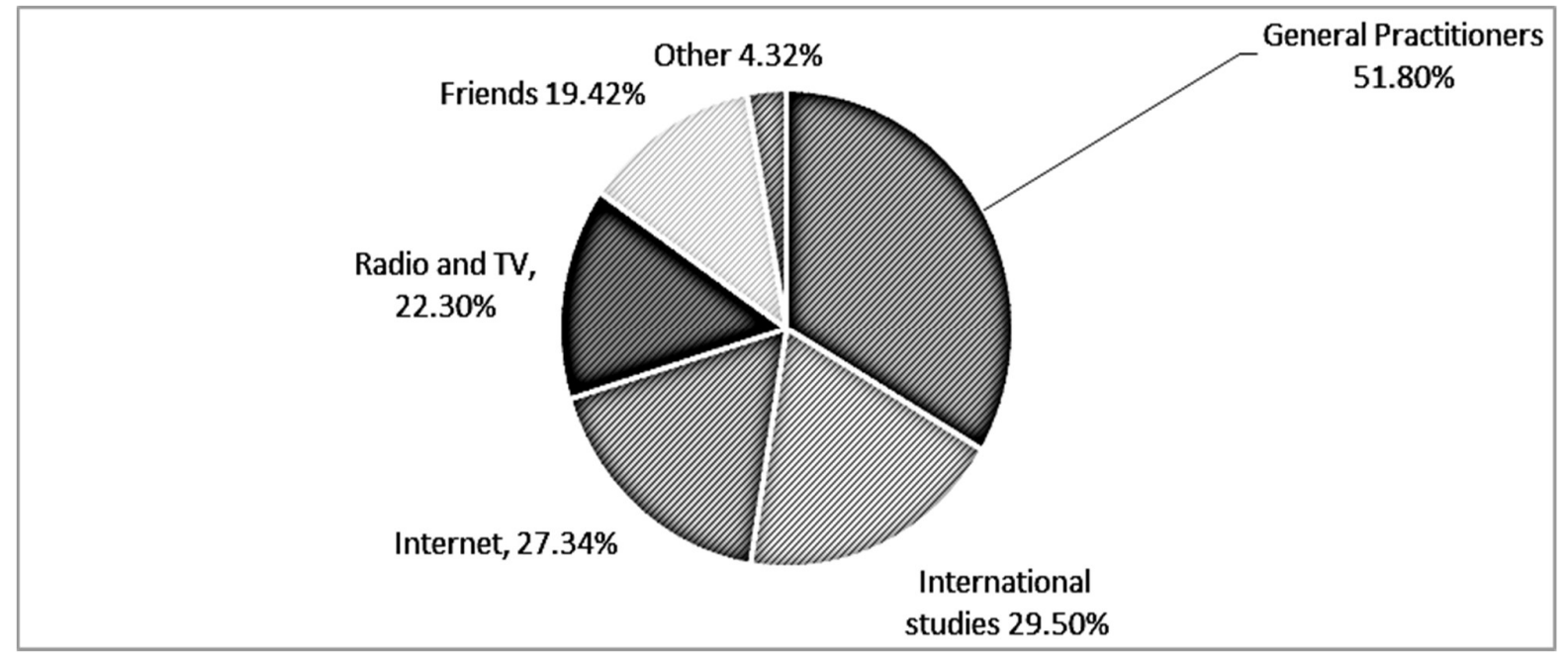

Fig. 2: Structure of the main sources of information about the benefits of vaccination

\title{
4. Why GP are Important for the Vaccination Process?
}

86 people who participated at the survey considered that vaccination is better if managed under general practitioners (GP) responsibility; 2 respondents did not provide any explanation for their choice. However, 28 individuals considered that the family doctor knows better both the child and family's medical history; so the vaccination should be done at his office. Another relevant reason, supported by 13 of the respondents, is the fact that the GP offers informed advice, shows the possible side effects and especially the benefits of vaccination, thus increasing parental compliance. 8 people raised the issue of the different age of children in the same class, or the fact that they may be deliberately absent to avoid vaccination, and thus highlighted the importance of observing the vaccination program that can only be done by the family doctor. Another reason was that the family doctor is also attending parents who can supervise the vaccination, support and help the child. When asked about alternatives to vaccination to prevent childhood illness, 77 questioned people said they did not know other alternatives. Increased importance was given to proper hygiene. 16 people considered important the information of the population through campaigns, through medical education courses made in primary classes or through governmental notification programs. A balanced and fixed program of sleep and nutrition based on fruits and vegetables was considered by 13 interviewees to be an effective prevention option. 


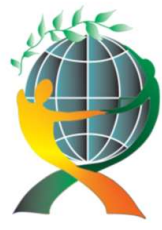

\author{
(online) $=$ ISSN $2285-3642$ \\ ISSN-L = $2285-3642$ \\ Journal of Economic Development, Environment and People \\ Volume 8, Issue 2, 2019 \\ URL: $\underline{\text { http://jedep.spiruharet.ro }}$ \\ e-mail: office jedep@spiruharet.ro
}

\title{
5. Conclusion
}

As a result of the data analysis, it appears that the female population was more interested in the subject of vaccination, as it responded to more questionnaires, although male subjects had equal access to completing the questionnaire. Fortunately, most of the respondents with children have a positive attitude towards vaccination. Except for one respondent, all the parents surveyed vaccinated their children. Although most respondents claimed that they knew the benefits of vaccination, less than half knew all the complications of preventable diseases by simply vaccinating. The fact that the hepatitis $B$ vaccine was last added to the list of mandatory vaccines in Romania was translated into a low number of respondents who knew this.

There is a good percentage of respondents' documentation from safe and informed sources about the details, information and benefits of child vaccination.

As for the main reason why some responders refuse to vaccinate their children was- "the influence of other parents" - it strikes that it has no scientific basis or eloquent explanation. This reason is found in a larger number among females compared to male gender. We tested the hypothesis that females are more inflexible than other males, but the difference between the two groups is not statistically significant ( $p>$ 0.05).

Higher educated people responded more correctly to general questions about vaccines than those without higher education. This result can also contribute to the fact that they are informed in a higher percentage than those without higher education, from well-known sources: specialist literature and family doctor. Most of the respondents want child vaccination to be done at the family doctor's office. There is no statistically significant difference between those with higher education and those without $(p>0.05)$, both of which give priority to the family doctor as regards the vaccination of children. Vaccination is considered safer when done by a family doctor because he / she better knows the patient's, family history and can provide real information and details about the possible adverse effects of vaccination. Nearly half of respondents consider appropriate to sanction parents who do not vaccinate their children, sanctions made up either in banning children from enrolling in educational institutions or fines. Unfortunately, an increasing number of respondents do not know how to distinguish between the myths and the truth and have erroneous information about vaccination, such as "it may cause autism" or that "it is pointless to vaccinate your child if the rest of the community is already vaccinated". Analyzing the data, it is noted that those without higher education offered the majority of the wrong answers compared to those with higher education, the difference being statistically relevant $(p<0.05)$. Respondents are aware of multiple alternatives to vaccination against child illness: proper hygiene, information campaigns, or proper nutrition.

Beyond the programs for the promotion of pro-vaccination, through proximity medical facilities and family doctors, an essential role is played by the full capacity to adequately support the benefits for the individuals and for the community, alongside the efforts made by the Health Coalition to advocate respect for the rights and the freedoms of the person with regard to access to and application of various procedures, treatments or medical interventions of any nature, ensuring respect for the supreme principles 


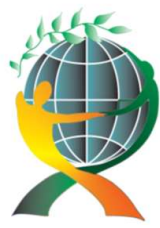

\author{
(online) $=$ ISSN $2285-3642$ \\ ISSN-L = $2285-3642$ \\ Journal of Economic Development, Environment and People \\ Volume 8, Issue 2, 2019 \\ URL: http://jedep.spiruharet.ro \\ e-mail: office jedep@spiruharet.ro
}

of the prevalence of individual interest towards society, integrity and physical security of the person and informed consent.

\title{
6. References
}

[1]. Abbas D., Lichtman A. and Pober J., (1994), Cellular and Molecular Immunology, $2^{\text {nd }}$ eds., Philadelphia: WB, Saunders Co.

[2]. Adegbola R.A., Secka O., Lahai G., Lloyd-Evans N., Njie A., Usen S., Oluwalana C., Obaro S., Weber M., Corrah T., Mulholland K., McAdam K., Greenwood B., and Milligan P.J., (2005), Elimination of Haemophilus influenza type b (Hib) disease from the Gambia after introduction of a Hib conjugate vaccine: a prospective study, Lancet, 366, pp: 144-50.

[3]. Andre F.E., (2005), What can be done to make vaccines more trendy?, Expert Rev Vaccines, Vol.4, pp: 23-5.

[4]. Angheluta, Andrei, Mihoreanu, Larisa, Costea, Carmen \& Stefanescu Alexandru, (2016), „The Health System Management In Countries With Financial Needs (CFN)", in D.Vrontis, Y.Weber, E.Tsoukatos (ed.) $9^{\text {th }}$ Annual EMAB Conf. on Innovation, Entrepreneurship and Digital Ecosystems, Euro Med Press, Krakow, Poland, pp: 98110 ,

ISBN:

978-9963-711-43-7, https://Scholar.Google.Ro/Scholar?Q=Mihoreanu+The+Health+System+Management+In+Countries+With+Fina

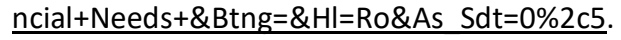

[5]. Benisheva-Dimitrova, Tatyana, Brborović, Ognjen, Donev, Doncho, Dyakova, Mariana, Džakula, Aleksandar, Eržen, Ivan, Farkaš-Lainščak, Jerneja, Fisk, Malcolm, Folmer, Herman R., Galan, Adriana, Georgieva, Lidia, Grujić Vera, Hristov Nikolay, Jakšić Želimir, Karadžinska-Bislimovska Jovanka, Karaslavova Emilia, Kirilov, Kiril, Košnik, Mitja, Kovačić, Luka, Krajc, Mateja, Lunder, Urška, Martinov, Cvejin, Mirjana, Mijakoski, Dragan, MilevskaKostova, Neda, Minov, Jordan, Možina, Miran, Pavlova, Jasmine, Premik, Marjan, Risteska-Kuc, Snežana, Rudel, Drago, Salchev, Petko, Santrić-Miličević, Milena, Scîntee, Silvia Gabriela, Shipkovensk,a Elena, Sidjimova, Dobriana, Stambolović, Vuk, Stikova, Elisaveta, Stoleski, Sašo, Sušteršič, Olga, Šogorić, Selma, Švab, Igor, Švab, Vesna, Trendafilova, Petya, Vodenicharov, Tzekomir, Vončina, Luka, Vukušić, Rukavina Tea, Wenzel, Helmut, Zaletel, Marija and Zaletel-Kragelj, Lijana, (2008), “Forum For Public Health in South Eastern Europe Programmes for Training and Research" in Doris Bardehle, Luka Kovačić, Ulrich Laaser and Oliver Razum - ed., (2008), Public Health Management in Health care practice A Handbook for Teachers, Researchers and Health Professionals, Kovačić Luka, Zaletel-Kragelj Lijana MetaNET and FPH-SEE Project Coordinators, Publisher: Hans Jacobs Publishing Company, Medicinska naklada, http://dnb.ddb.de abrufbar.

[6]. Braveman, P., Starfield, B. and Geiger, H.J., (2001), World Health Report 2000: how it removes equity from the agenda for public health monitoring and policy, BMJ, Vol. 323(7314), pp: 678-681.

[7]. Brawley, O., Byers T, Chen, A.Y., Pignone, M., Ransohoff, D., Schenk, M., Smith, R., Sox, H., Thorson, A. and Wender, R., (2011), New American Cancer Society Process for Creating Trustworthy Cancer Screening Guidelines, JAMA, Dec. 306 (22), pp: 2495-2499, http://jamanetwork.com/journals/jama/articleabstract/1104727.

[8]. Brugha, R. and Zwi, A., (1998), Improving the quality of private sector, delivery of public health services: 


\author{
(online) $=$ ISSN $2285-3642$ \\ ISSN-L = $2285-3642$ \\ Journal of Economic Development, Environment and People \\ Volume 8, Issue 2, 2019 \\ URL: http://jedep.spiruharet.ro \\ e-mail: office jedep@spiruharet.ro
}

challenges and strategies, Oxford Journals, Health Policy and Planning, Vol.13 (2), pp: 107-120.

[9]. Centers for Disease Control and Prevention, (2017), Epidemiology and Prevention of Vaccine-Preventable Diseases, Hamborsky J, Kroger A and Wolfe S.- ed., $13^{\text {th }}$ eds., Supplement, Washington D.C., Public Health Foundation.

[10]. Centrul Național de Supraveghere și Control al Bolilor Transmisibile (2017), Analiza evoluției bolilor transmisibile aflate în supraveghere. Raport pentru anul 2016, http://www.cnscbt.ro/index.php/rapoarte-anuale/779analiza-evolutiei-bolilor-transmisibile-aflate-in-supraveghere-raport-pentru-anul-2016/file.

[11]. Chabot I., Goetghebeur M.M. and Gregoire J.-P., (2004), The societal value of universal childhood vaccination, Vaccine, vol.22, pp: 1992-2005.

[12]. Chang, M.H.,(2003), Decreasing incidence of hepatocellular carcinoma among children following universal hepatitis B immunization, Liver Int; Vol.23, pp: 309-24.

[13]. Ehreth J., (2003), The global value of vaccination, Vaccine; Vol.21, pp: 596-600.

[14]. Lancaster, Jeanette and Stanhope, Marcia, (2011), Public Health Nursing, Pageburst on Kno Retail Access Code: Population-Centered Health Care in the Community, $8^{\text {th }}$ eds., Elsevier Science Health Science Division, ISBN: $0323170188,9780323170185$.

[15]. McMichael, Anthony and Robert Beaglehole, (2009), "The global context for public health" (2009), in Robert Beaglehole and Ruth Bonita (ed.) (2009), Global Public Health: A new era, $2^{\text {nd }}$ eds., OUP UK.

[16]. Mihoreanu Larisa, (2016), PhD Report III Reconstructing the Healthcare System White Paper.

[17]. Parker A.A., Staggs W., Dayan G.H., Ortega-Sánchez I.R., Rota P.A., Lowe L., Boardman P., Teclaw R., Graves C., LeBaron C.W., (2006), Implications of a 2005 measles outbreak in Indiana for sustained elimination of measles in the United States, N Engl J Med., Vol.355(11), pp: 1184, PMID:16885548, DOI:10.1056/NEJMoa060775.

[18]. Pearce J., (2005), Poliomyelitis (Heine-Medin disease), J Neurol Neurosurg Psychiatry, Vol. 76(1), pp: 128.

[19]. Perelson, A.S., (1989), Immune network theory, Immunol. Rev., 110, pp. 5-36, https://www.ncbi.nlm.nih.gov/pubmed/2477327

[20]. Petrakova, Alena and Sadana, Ritu, (2007), Problems and progress in public health education, Bulletin of the World Health Organization, Vol. 87, http://www.who.int/bulletin/volumes/85/12/07-046110/e.

[21]. Santamaria, Pere, (2010), The Long and Winding Road to Understanding and Conquering Type 1 Diabetes, Immunity, Vol. 32, Issue 4, pp: 437-445, https://doi.org/10.1016/j.immuni.2010.04.003.

[22]. Swartz, Nikki, (2004b), Doctors, Hospitals Advised to Keep Records Electronically, Information Management Journal, Vol. 38(1), p: 9.

[23]. Tarlov, Alvin R., Ware Jr., John E., Greenfield, Sheldon, Nelson, Eugene C., Perrin, Edward and Zubkoff, Michael, (1989), The Medical Outcomes Study an Application of Methods for Monitoring The Results of Medical Care, AMA Journal, Vol. 262(7), pp: 925-930.

[24]. WHO, (2004), Polio reported in Botswana, Geneva, http://www.who.int/mediacentre/notes/2004/np11/en. 


\author{
(online) $=$ ISSN $2285-3642$ \\ ISSN-L = 2285 - 3642 \\ Journal of Economic Development, Environment and People \\ Volume 8, Issue 2, 2019 \\ URL: http://jedep.spiruharet.ro \\ e-mail: office jedep@spiruharet.ro
}

[25]. WHO, (2006), Position paper on Haemophilus influenza type b conjugate vaccines, Weekly Epidemiol Rec; Vol.81, pp: 445-52.

[26]. World Health Organization, (2014), World Cancer Report 2014, Chapter 1.

[27]. WHO, (2017), World Immunization Week, 24-30 April, http://www.who.int/campaigns/immunizationweek/2017/en/.

[28]. WHO, (2019), Vaccine and immunization quality and safety, Immunization, Vaccines and Biologicals, https://www.who.int/immunization/quality_safety/en/

[29]. World Health Organization, Regional Office for the Western Pacific (2017), Eliminating measles and rubella [fact sheet], Manila, http://iris.wpro.who.int/handle/10665.1/13658

[30]. WHO, (2019),Ten threats to global health in 2019, https://www.who.int/emergencies/ten-threats-to-global$\underline{\text { health-in-2019 }}$

[31]. WHO,(2019), Vaccines and the power to protect, Immunization, Vaccines and Biologicals, https://www.who.int/immunization/en/ 